\title{
Understanding the Implications of Alternative Bioenergy Crops to Support Smallholder Farmers in Brazil
}

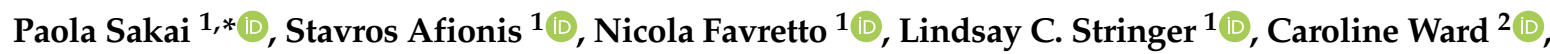 \\ Marco Sakai ${ }^{3}{ }^{\circledR}$, Pedro Henrique Weirich Neto ${ }^{4}{ }^{\circ}$, Carlos Hugo Rocha ${ }^{4}$, Jaime Alberti Gomes ${ }^{4}(\mathbb{D}$, \\ Nátali Maidl de Souza ${ }^{4}\left(\mathbb{D}\right.$ and Nouman Afzal ${ }^{1}$ (i) \\ 1 Sustainability Research Institute, School of Earth and Environment, University of Leeds, Leeds LS2 9JT, UK; \\ s.afionis@leeds.ac.uk (S.A.); n.favretto@leeds.ac.uk (N.F.); 1.stringer@leeds.ac.uk (L.C.S.); \\ ee18na@leeds.ac.uk (N.A.) \\ 2 Leverhulme Centre for Anthropocene Biodiversity, University of York, York YO10 5DD, UK; \\ caroline.ward@york.ac.uk \\ 3 Department of Environment and Geography, University of York, Heslington, York YO10 5NG, UK; \\ marco.sakai@york.ac.uk \\ 4 Laboratório de Mecanização Agrícola (Lama), Universidade Estadual de Ponta Grossa, Campus Uvaranas, \\ Ponta Grossa/PR 84030900, Brazil; lama1@uepg.br (P.H.W.N.); chrocha@uepg.br (C.H.R.); \\ jagomes@uepg.br (J.A.G.); natalimaidl@uepg.br (N.M.d.S.) \\ * Correspondence: p.h.m.d.oca@leeds.ac.uk
}

Received: 4 February 2020; Accepted: 3 March 2020; Published: 10 March 2020

\begin{abstract}
Smallholders constitute more than three quarters of the world's farmers, and despite their numbers, they commonly lack opportunities to advance their development status. Bioenergy production and consumption can help sustain smallholders' energy needs and generate employment and income, but it also raises concerns over social justice and equity, especially where crops used for bioenergy could also be used for food. This perspective paper is grounded in a literature review related to three different crops in Brazil: sugarcane, landrace maize and sweet potato. It seeks to determine if these crops offer the potential to support smallholder farmers' development in a more equitable way, focusing on opportunities for their use in bioenergy. We review the literature to identify policies shaping the smallholder development context in relation to these crops, assessing whose knowledge informs policy and institutional decision making, and highlighting the policy attention afforded to the different crops from different sectors. We further evaluate the literature on each crop in relation to water use and calorific value (i.e., food and energy). Our review indicates that while sugarcane has received the most policy and institutional attention, its development is largely anchored in research and development investments that support large-scale commercial farms and agri-businesses. Smallholders have not benefited or had the opportunity to engage in relevant policy decision making for sugarcane cultivation. At the same time, smallholders hold valuable untapped knowledge on the cultivation of sweet potato and landrace maize, both of which have the potential to generate development opportunities for smallholders. Our review suggests that the environmental impact of landrace maize and sweet potato in terms of water use is significantly lower than sugarcane, while they can generate more calories for energy or food consumption and offer diversification opportunities. Despite that these alternative crops offer considerable untapped potential to support rural development, more research is still needed to harness these benefits. Changes are needed to address inequities in policies, institutions and the types of knowledge informing decision making. Such changes need to afford smallholder farmers greater recognition and participation in decision making, so that the distribution of benefits from the three study crops can reach them to support their development better.
\end{abstract}


Keywords: sugarcane; sweet potato; biofuels; development; landrace corn; landrace maize; water-energy-food nexus; policy-institutions-knowledge nexus

\section{Introduction}

Smallholders are commonly defined as farmers with limited resources, including land, compared to other farmers within the same sector and country context [1]. Globally, smallholder farming constitutes $75 \%$ of agricultural land worldwide, with the livelihoods of two billion people depending on the production of 570 million small farms [2]. This generates a substantial share of the world's food production, particularly across Africa and Asia, where smallholder farming provides $80 \%$ of the food consumed, with some crops also used as animal feed and for energy generation [2]. The majority of smallholder households around the globe live in poverty [3]. A range of interrelated factors limit smallholders' development [4], and can keep them trapped below the poverty line, including a lack of access to water, energy, credit, knowledge, inputs and markets, underdeveloped system of collecting and selling crops, each of which constrains the efficient use of land, output commercialisation and revenue generation [5]. Furthermore, poor health, sanitation and education hamper smallholders' ability to develop new skills and access and use information or technology. The challenges to open up bioenergy crops to support smallholder farmers lie in re-aligning policies that now favour large-scale agribusinesses towards unlocking opportunities for smallholder farmers to access new markets, finance, and research to enable a landscape where they can advance a sustainable, socially-just and equitable future.

The focus of this paper is on Brazil, where smallholders are defined by the Federal Government as those rural farmers who practice farming activities on an area smaller than four fiscal modules [6], where each module ranges from 5 to 110 hectares depending on the municipality [7]. To ease agricultural and rural development constraints in Brazil, bioenergy production and consumption have been pursued to help satisfy energy demand, generate rural employment, increase and diversify farm income and manage environmental degradation [8-10]. The bioenergy industry, however, has been dominated by large agribusinesses, hardly favouring the integration of smallholder farmers [11]. The use of biofuels in Brazil as an alternative to fossil fuels has a long history. Bioethanol, in particular, has formed a core part of the Brazilian energy strategy since the adoption of the National Alcohol Program (ProÁlcool) in 1975, launched as a response to the petroleum crises of the 1970s and falling sugar prices [12]. Nowadays, in Brazil, sugarcane ethanol production provides a higher worker income compared to the vast majority of other agricultural sectors and generates six times more jobs than the Brazilian petroleum sector [13]. However, these opportunities do not target smallholders, and indeed, can disadvantage them. For example, bioenergy deployment can have strong distributional and other sustainability-related impacts [14], like loss of access to productive land, or dwindling, or replacement of family and community-based agriculture as large-scale agribusinesses take over.

Smallholder farmers have been left out from the ethanol production system in Brazil, where policies have created unintended consequences. Impacts to smallholder farmers are related to a confluence of factors, such as the type of bioenergy option [15], and often, the persistence of sectoral approaches to policymaking supporting large-scale agribusinesses [11]. This has undermined both sustainable development in the long term, as well as the livelihood security of local stakeholders in the short term [16]. These issues leave us with an important knowledge gap as to how the outcomes of such policies can be more equitable. Ensuring development efforts are equitable is important because a focus only on distributional aspects may mean that some groups, like smallholder farmers, end up being further marginalised, leaving policy to overestimate what can be achieved and neglecting consideration of unwanted side-effects and trade-offs [17].

The introduction of the National Program of Production and Use of Biodiesel (PNPB) in 2004 signalled a recognition on the part of the Brazilian government of the need to foster more sustainable 
practices in the biofuel value chain. Research is emerging around the world, and in Brazil, on the promising potential of alternative crops to sugarcane to meet the demands for biofuel production, and it has been suggested that these new crops can help small scale farming systems. Sawyer, et al. [18], for example, explored alternative bioenergy crops, but their implications for development at different scales have not been sufficiently assessed, particularly in relation to their socio-economic impacts. Sweet potato and corn have been highlighted as particularly suitable for biofuel production by smallholder farmers $[19,20]$, but unanswered questions remain relating to current development challenges and knowledge gaps in relation to issues of social justice, environmental equity and economic equity for smallholder farmers.

This paper seeks to offer a perspective on the challenges and opportunities linked to alternative bioenergy crops, namely, landrace maize and sweet potato, for smallholder farmer livelihoods. We explore the literature to determine if those crops can offer more equitable sustainable development in Brazil that does not leave smallholder farmers behind. We concentrate on sweet potato and landrace maize, since they represent common crops grown by smallholders in Brazil [21,22]. We examine previous studies to compare and contrast these crops against sugarcane, as the mainstream bioenergy source. Also, we investigate which policies are shaping the smallholder development context in specific relation to these three crops; what the key institutions are involved in shaping the context for farming and rural development; which groups they recognise; and what types of knowledge they rely upon at different levels. Water, food, and energy security are vital goals in sustainable development efforts; thus, we revise the literature to unpack the relative magnitude of the impact that the study crops could have on those, while also identifying how the processes for ensuring smallholders have a voice in shaping the policy and institutional context can be enhanced.

\section{Conceptual Framing and Methodological Approach}

It is key to identify the potential winners and losers in the deployment of bioenergy crops in order to ensure that development outcomes are both equitable and just, particularly for smallholders $[16,23]$ across all three dimensions of justice: distributive, procedural and recognition [24]. The distributive dimension ('who gets what' - ensuring benefits and costs are not unevenly distributed spatially or temporally), has often had the greatest focus in academic research. However, it is also important to ensure that all stakeholders are able to participate in decisions that may impact them (procedural justice) and that the rights, values, interests and priorities of all actors are acknowledged and accepted (recognition justice) [24]. These dimensions are not standalone, and can both reinforce or undermine each other [25]. Taking a justice or equity focus is not just important from a moral point of view. Evidence demonstrates that environmental interventions are more likely to succeed when they are equitable [26,27]. Issues of equity and justice have often been raised in reference to one part of the water-energy-food (WEF) nexus, but rarely integrating all three [28]. For example, there have been various campaigns to highlight the human right to accessing food, water and energy and prevent 'grabbing' of resources by individuals, private companies or other countries [29,30]. However, studies have highlighted that development interventions that improve access to these resources are not necessarily impacting all parts of society equally [28,31]. Applying a justice lens to nexus studies can improve understanding of decision-making processes, while taking a nexus approach can improve understanding of the linkages between water, energy and food [28]. The literature includes a range of holistic approaches that seek to examine interlinkages and trade-offs across scales, often in relation to the WEF nexus. In this paper, we apply a modified version of the WEF-PIK (water-energy-food-policies-institutions-knowledge) framework developed by Stringer, et al. [23] to guide our literature review and to identify the challenges and opportunities of using different bioenergy crops to advance smallholder farmers' development (Figure 1). 


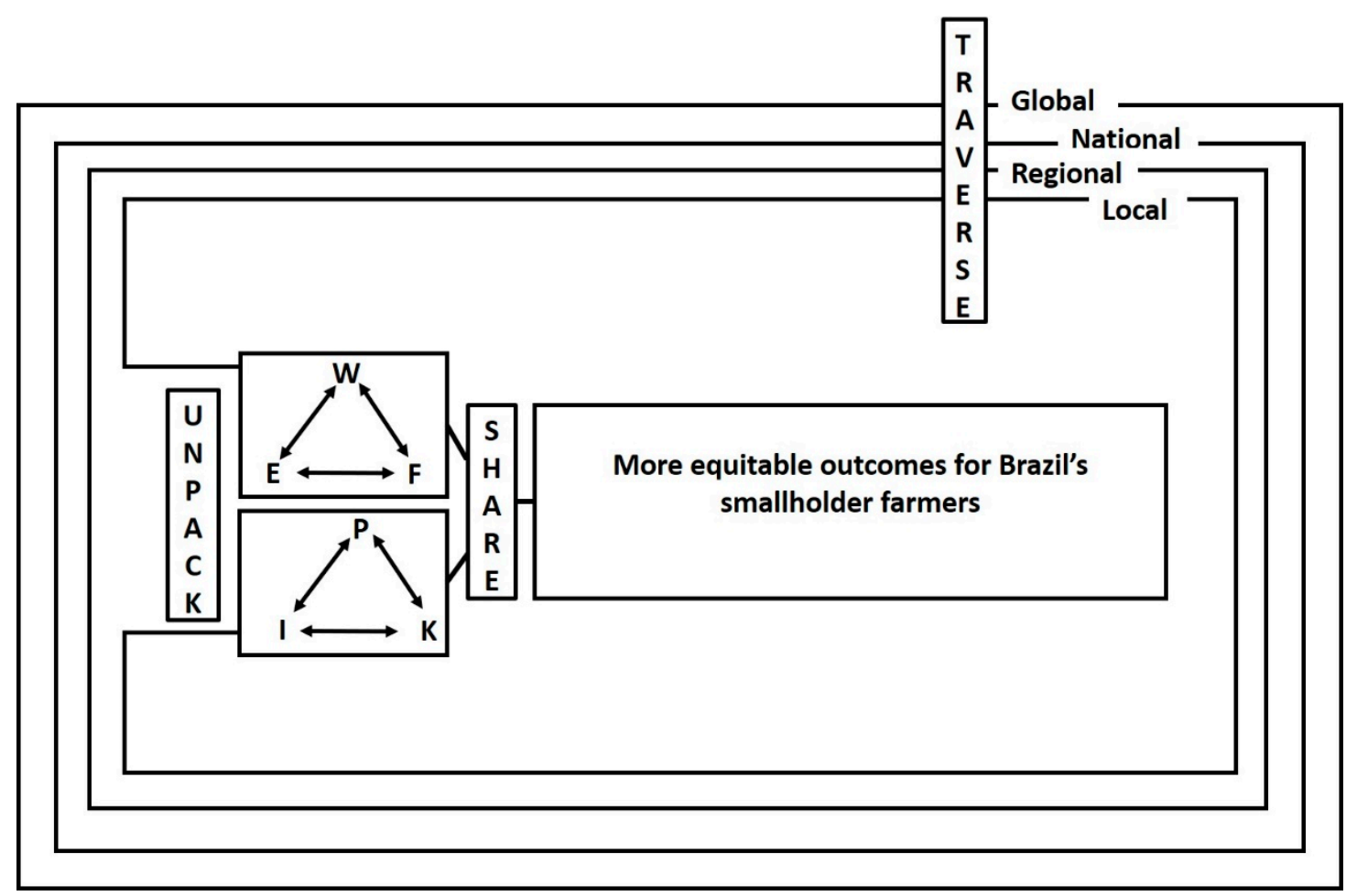

Figure 1. Modified WEF-PIK (water-energy-food-policies-institutions-knowledge) framework as applied to the Brazilian case.

The WEF-PIK framework was selected as it enables a specific focus on issues of justice and equity; and its utility compared to other nexus approaches is that it explicitly considers governance dimensions through its incorporation of a second nexus: PIK (policies, institutions and knowledge). This steers us to look not just at the distribution of winners and losers across smallholder farmers and other groups and the WEF nexus, but also to consider the PIK that shape those distributions. Policies and institutions across scales are guided by particular (often formal) knowledge (rather than more informal experience and know-how held by smallholders). Institutions mediate these different forms of knowledge, elevating some and dismissing others. This can result in a lack of recognition, meaning that other ways of knowing, aside from formal knowledge, are marginalised in policy and decision making. The PIK is influenced by the political landscape and existing power structures (see Section 3). In turn, this contributes to shaping the distributions of "winners" and "losers". The framework guides us as we "unpack" relationships in and between each nexus; "traversing" different scales from the global to local; and identify opportunities to share knowledge to deliver more equitable outcomes for smallholder farmers [23,32].

Given the scarcity of relevant peer-reviewed literature of acceptable quality on alternative bioenergy crops and smallholder farmers in Brazil, a systematic review proved inadequate. Hence, we follow the review approach proposed by Levy and Ellis [33]. The review comprised three key steps. First, the literature was searched and screened, including peer-reviewed literature, policy documents, regulations and grey literature. A list of keywords was generated but, as results were scarce, a non-systematic approach was followed, i.e., the information was extracted from primary articles and policy documents without setting specific inclusion/exclusion criteria, as per conventional literature review. Once the data was extracted, which is part of the second step described by Levy and Ellis [33], it was analysed using the narrative review method [34]. Grounded in a qualitative interpretation of the current state of knowledge, this review aims to summarise available information on the prospective challenges and opportunities linked to alternative bioenergy crops for equitable smallholder farming in Brazil, rather than seeking empirical generalisation. Moreover, the review allowed the identification of various knowledge gaps that require further research. 


\section{The PIK Nexus}

Crop-based liquid biofuel production (such as ethanol and biodiesel) has grown rapidly in recent years, fuelled by an interplay between public policies and market mechanisms. Climate change mitigation, energy security and rural development stimulation have commonly been highlighted as the main factors driving global biofuel expansion [35]. Many of these drivers are influenced by international and national market and policy interactions, often informed by scientific knowledge, as well as local customs and norms. These PIK interact within and across international, national and local levels, traversing scales, while their combined impacts affect ecosystems' ability to deliver WEF security and support socio-economic resilience.

Pilgrim and Harvey [36] refer to the biofuels market as "politically instituted", noting that the aforementioned expansion was fuelled by an assortment of government economic incentives, such as tax breaks, subsidies or preferential loans from public banks. The United States, Brazil, and the European Union are chiefly responsible for the rapid global expansion of biofuels in recent years, jointly accounting for close to $90 \%$ of global biofuel production [37]. The substantial expansion of biofuel production has led to the introduction of a number of market-oriented or sustainability-oriented multilateral initiatives to facilitate the acceleration of production and commercialisation of biofuels. The Global Bioenergy Partnership (GBEP), the International Energy Agency (IEA), several United Nations agencies, like the Food and Agriculture Organisation (FAO), and the various biofuels certification schemes that have sprung up as international responses to sustainability concerns, offer examples of bodies seeking to foster sustainable international biofuel trade [38].

At the national level, although governments in the US and the EU have only been engaged in biofuels since the 2000s, ethanol production in Brazil has a long and far more contentious history. ProÁlcool, the 1975 government programme governing the biofuels value chain, initially envisaged the stimulation of alcohol production by sugarcane, sweet potato, cassava and other relevant crops [11]. Unable to compete with the large-scale and efficient production of the sugarcane sector, with roots linked to the large plantations of the colonial times, other crops were eventually discarded, leaving sugarcane as the dominant crop for ethanol production in Brazil [39]. This resulted in a policy environment heavily influenced by large sugarcane interests, side-lining smallholder agriculture, and the marginalisation of alternative biofuel crops.

Back in the 1970s, attempts were also made to introduce biodiesel, but lack of supply and infrastructure hindered effective deployment at the national level [40], which highlights that structural problems need to be addressed, so policies are able to deliver intended outcomes. Renewed efforts were undertaken with the promulgation of the 2004 PNPB which, in addition to advancing biodiesel as a transportation fuel, also sought to confront the aforementioned problems and foster the social inclusion of family farmers through participation in the biodiesel chain. Social inclusion is supported by the Social Fuel Seal (SFS), which can only be obtained by those biodiesel producers that purchase a percentage of their raw material from family farmers. Results to date, however, have been mixed, with dysfunctions in the overall operation of the SFS having compromised its ability to make biodiesel more socially sustainable [41]. For instance, by actively supporting the development of cooperatives as a means of enhancing small-scale farmer social inclusion, the Brazilian government has marginalised in the process those subsistence farmers who have not organised themselves into such schemes [40].

A host of social and environmental implications have been documented, due to these policy paths, with Stattman, et al. [40] (p. 22) listing "geographical concentration, single crop focus, dominance of agribusiness, and exclusion of family farmers" as among the most pertinent. An array of other unsustainable production practices have also been highlighted, ranging from poor labour conditions [42], and rampant unemployment, due to increasing mechanisation of farming practices [43] to land-use change [44], water depletion [45], and competition with food crops [46]. 


\subsection{Policies}

Only in recent years have there been efforts to deal with the legacy of significant social and environmental costs of bioethanol production in Brazil and strengthen the sustainability profile of the Brazilian sugarcane ethanol sector. Such efforts are in line with the promulgation of biofuel policies containing sustainability requirements and criteria among Brazil's main trading partners, notably the US and EU [47]. A host of domestic policies are relevant to the development of sustainable bioenergy-related activities in Brazil, such as the 2012 Native Vegetation Law, ordinarily called the new Forest Code, which promulgates the "mandatory protection and, in some cases, restoration of native vegetation around water springs and along riparian buffers" [48] (p. 50). The width of the stream or river, the size of the property and the type of biome determine the area of forest protection. For example, the Forest Code requires landowners to conserve $80 \%$ of the native forest in private property in the Amazon region, with figures for the Cerrado region and the remaining Brazilian biomes being $35 \%$ and $25 \%$, respectively [ 49 ].

The primary planning instrument at the federal level regulating sustainable sugarcane expansion is the Agro-Environmental Zoning program (ZAE Cana), developed by EMBRAPA and launched in 2009. Based on information on agricultural potential, potential climate risks, environmental regulations, as well as surface and underground water availability and vulnerability, ZAE Cana excludes sugarcane cultivation in sensitive ecosystems like the Amazon, the Pantanal wetlands or the Upper Paraguay river basin [47]. It instead prioritises expansion in areas perceived as agronomically, climatically and environmentally more suitable, such as under-used areas or degraded pastures. Views on its effectiveness, however, are rather polarised. For example, Mercure, et al. [46] (p. 236) argue that ZAE Cana is a "technical instrument of a merely indicative nature", which pays no attention to the potential for competition between sugarcane and food production. Nogueira and Capaz [50], in turn, take a more favourable stance and maintain that Brazilian biofuels contribute to food security and have a negligible impact on food production.

At the state level, the main (voluntary) regulatory instrument is the 'Etanol Verde' (Green Protocol) programme, launched in 2007 and developed by the state of São Paulo and the Brazilian Sugarcane Industry Association (UNICA). The programme sets out a number of commitments and technical objectives, such as preventing soil erosion, conserving water resources, phasing-out pre-harvest field burning, and protecting riparian forests [51]. Appraisals so far have been positive, with Mercure, et al. [46] noting that it has performed well in eliminating sugarcane burning, and Benites-Lazaro, et al. [47] (p. 586) calling the programme "an important achievement" that has promoted the incorporation of sustainable practices in the sugarcane sector.

To ensure the continued success of its biofuels policy, which is also a cornerstone in its efforts to mitigate climate change, Brazil is planning to substantially increase the share of biofuels in the Brazilian energy mix. Under the 2015 Paris Agreement on Climate Change, Brazil pledged to reduce its greenhouse gas emissions by $43 \%$ below 2005 levels by 2030 [52]. As part of its implementation strategy, the Brazilian government launched in 2017 the "RenovaBio" program, which sets a target of increasing ethanol production from 28 billion L per year in 2015 to around 50 billion L per year by 2030 [53]. Doubts, however, have been expressed with regard to the ability of the "RenovaBio" programme to guarantee the sustainable production of biofuels, especially with respect to land use change and disruption of food supply [54].

As the above discussion illustrates, smallholder farming in Brazil has historically taken a secondary and subordinate role to large-scale sugarcane agribusiness. The latter has garnered the bulk of policy attention from Brazilian policymakers, eager to ensure its modernisation and reproduction [55]. Focus on cash crop production over food crops further alienated smallholder farmers. As Rocha, et al. [56] (p.521) note: "Small, family production has always been considered a marginal, and even dispensable, part of the agricultural economy. Until the 1990s, there was little recognition [in Brazil] of the family farm sector's real and potential economic contribution. In fact, for most of the country, small rural 
producers were something to be dealt with as a 'social problem', given the widespread poverty among rural families, and their demands for agrarian reform and land settlements."

It was only in the late 1990s, following a long period of neglect, that Brazilian governments initiated policies designed to favour smallholder farmers. It should be noted, however, that none of the aforementioned policies seeks to promote landrace maize or sweet potato ethanol production, despite their great potential (see Section 4) [57-61].

The main instrument to promote sustainable development of smallholder farming in Brazil is the National Program for Strengthening Family Farming (PRONAF), established in 1996 as a political response to the social mobilisation of the sector. PRONAF provides support for "modernization (sic) and/or acquiring new machinery and equipment related to soil improvements, milk coolers, the genetic improvement of production factors (plants and animals), irrigation systems, orchards, greenhouses and storage as well as investments in tourism activities, such as craft workshops and cottages" [62] (p. 3). However, while PRONAF offers credit for a wide range of crops [63], most has been directed to finance inputs within intensive farming systems [64]. More recently, it has supported sustainable farming practices (e.g., PRONAF-Agroecology and PRONAF-Forest), and other groups (e.g., PRONAF-Women and PRONAF-Youth), but again, access to this credit is often far from straightforward for smallholder farmers. One of the reasons is the need to comply with Agricultural Climate Risk Zoning provisions. The latter is an instrument of agricultural policy and risk management in agriculture, "guiding the farmer about the best planting and sowing of crops season, in order to reduce agricultural losses" [65]. However, several alternative crops common to smallholder farming, such as sweet potato and landrace maize, are not considered in official studies of climatic risk zoning. Even so, farmers can opt to use their own seeds and still apply for PRONAF credit. If, however, the harvest fails, they will not be able to access insurance. Despite the important results in reducing rural poverty [66], it maintains a concentration of resources and contracts on more capitalised, cash-crop farmers (mainly corn and soybeans), reinforcing its strong productivity-based bias [67]. Lack of trained human resources for technical assistance and project design and socio-economic viability analysis at financial institutions represent additional constraints for directing the policy to support more sustainable farming practices (e.g., that do not rely on toxic chemicals) and socio-economic development.

Another policy that is pertinent here is the National School Nutrition Program (PNAE), a federal public food procurement program that enables public schools to offer free meals to students through the purchase of locally and regionally produced food [68]. There is also the Organic Food for School Meals launched in 2010 and the National Plan of Organic and Agroecology production (PLANAPO). In addition to improving the nutritional quality of school meals, these programmes have stimulated the creation of new markets for small-scale farmers. A final policy that merits mention is the 2003 National Technical Assistance and Rural Extension Policy (PNATER), which aims to promote or support processes of "agroecological training, exchange of experiences and knowledge, research-action, and technical support to families and producer communities" [69] (p. 794). This offers scope to bring together different kinds of knowledge to build human capital in agricultural production. A number of practical experiences related to this policy are found across Brazil, and include the provision of extension services for agroforestry development, organic certification of agricultural products, and the strengthening of agroecology in federal universities [70].

\subsection{Institutions}

Brazil's single-crop policy focus has resulted in the progressive establishment of an institutional infrastructure primarily tasked with paving the way for large-scale sugarcane ethanol production to become an integral component of the Brazilian energy matrix. At the national level, the two major government players in the Brazilian sugarcane ethanol sector are the Ministry of Agriculture and the Ministry of Energy, with the Ministry of the Environment also playing an important controlling role [71]. Illustrative of the high priority accorded to sugarcane is that the National Energy Policy Council (CNPE), which coordinates biofuels policy formulation, is supported by two separate inter-ministerial 
councils, one for sugarcane ethanol and one for biodiesel. An equally important institution is the National Agency of Petroleum, Natural Gas and Biofuels (ANP), which is the regulatory agency overseeing activities undertaken by energy industries in Brazil. Ethanol production has received substantial support from public funding, with the Brazilian National Bank for Economic and Social Development (BNDES) having a department dedicated to biofuel-related investments [37]. Other state-owned institutions, like the now-extinct IAA, the Institute of Sugar and Alcohol created in 1933, and more recently, EMBRAPA, the Brazilian Agricultural Research Corporation, have played a pivotal role in improving sugarcane cultivation over recent decades [72]. Universities and research centres, at both federal and state levels, have also been particularly active in improving agro-industrial and ethanol production technologies, while funding bodies, such as the Research Support Foundation of the State of São Paulo (Fapesp), have invested heavily in supporting sugarcane research and development activities [73]. An inter-university network for the development of sugarcane industry in Brazil (RIDESA), formed by an agreement between ten public universities and public-private partnerships, has been playing an important role in the development of more resistant crops to pests, diseases and water stress.

With three-quarters of Brazil's biofuel production consisting of sugarcane ethanol, and large-scale farms accounting for the bulk of it, the participation of smallholder farmers and local institutions in the Brazilian ethanol sector is considerably limited [11]. Structural issues are the root cause of these problems, because without opportunities to compete, smallholders are often forced to sell their land and seek alternative livelihoods either in the nearby cities or in local sugar fields, where only precarious jobs exist $[74,75]$. In addition, Brazil's institutional framework has historically prioritised energy security and financial attractiveness, with limited consideration for ethanol's ecological impact (e.g., water footprint) and potential competition with food production [46]. Only since the late 2000s have Brazilian institutions promulgated policies discussed by all levels of stakeholders, aimed at enhancing the sustainability of the sugarcane production system [76]. As Stattman, et al. [40] note, while the Brazilian sugarcane industry and government remain the dominant actors, domestic and international civil society organisations increasingly scrutinise the environmental and socio-economic performance of the sector.

In the sugarcane sector, the number of small, non-capital-intensive, poor landholders producing cane for the sugar/ethanol industry is negligible, thereby eliminating the need for institutionalisation of programs of financial and technical support. This is not the case as far as other crops are concerned, with the Brazilian government having undergone (until recently) an intense process of institution building in order to support smallholder farmers. For instance, PRONAF came under the remit of the Ministry of Agrarian Development (MDA) until 2016, the year in which the latter was replaced by the Secretariat for Family Agriculture and Agrarian Development, linked to the Office of the President. The abolition of the MDA, however, as well as of other agencies linked to rural development, has been viewed as signalling the progressive marginalisation of family agriculture in the highest echelons of government [77]. Turning to PNAE, school feeding falls under the remit of the National Fund for Development of Education (FNDE), a structure linked to the Ministry of Education. Implementation is strongly regulated, with each executing unit (e.g., municipal government) required to have a nutritionist "who is in charge of the elaboration of menus in line with nutritional norms" [78]. For rural development policies and extension, every state has a rural extension organisation that is supported by a host of municipal, state and federal government resources. Besides these state agencies, PNATER also allows for civil society organisations, farmer associations, and rural unions to engage in the provision of rural extension services [79]. In addition to formal institutions, the Brazilian smallholder sector is characterised by several informal institutions and practices, such as traditions, cultural expectations or social movements. A pertinent example is the land settlements of the Movimento dos Trabalhadores Rurais Sem Terra (MST). This movement occupies the land with high risks (including to life) and constantly strive for the rights of its members. When the settlements become formally recognised, the 
settled farmers organise themselves into cooperatives, to the point that they become a source of organic food production for the formal market [80].

\subsection{Knowledge}

In addition to high rates of investment, effective learning and innovation are key for stimulating economic growth. Etzkowitz and Leydesdorff [81] refer to the triad of university, industry and government relations as being instrumental in generating knowledge infrastructures. It is the interactions between these three actors that largely shape the evolution of institutions and policies aimed at spurring investment [82]. In the case of sugarcane in Brazil, such interactions have paved the way for the current model of large-scale agro-industrial development, with the consequent "radical transformation of natural ecosystems, local customs, and social relationships" [83] (p. 1321). Such approaches have resulted in local actors being marginalized and local knowledge being excluded from decision-making processes related to regional development, leading to a lack of recognition and procedural justice.

When it comes to sweet potato and landrace maize though, local knowledge still receives attention and recognition, and there are relationships that draw upon both expert and local knowledge. Starting with sweet potato, there are universities in Brazil, like the Federal University of Tocantins or the State University of Ponta Grossa, that have set up research centres focusing on furthering understanding of its potential for food and biofuel production. Local knowledge is pertinent here, as researchers actively seek local knowledge to inform their project design. Local NGOs and research institutions in some Brazilian states, like Paraná in southern Brazil, are also active in organising informal knowledge exchange and seedling fairs which bring together farmers, as well as researchers, creating a platform for knowledge sharing. However, this local knowledge does not reach the mainstream formal knowledge. EMBRAPA has also looked into breeding and developing sweet potato varieties for food consumption [84]. The capacity of sweet potato, as a more nutritious food and as a source for climate change adaptation, has been recognised on an international level [85], with the International Potato Centre, for instance, seeking to develop innovations that enhance farmer capacity to produce this crop [86].

Regarding landrace maize, knowledge generation activities receive greater support compared to sweet potato and take place in a more integrated manner. Conventional corn research has a substantial profile, with a significant body of literature, for instance, looking into the potential of using corn to produce ethanol [59]. The energy output of crops shows high positive correlations with research investment [85]. Consequently, landrace maize has benefited from increased research activity in this area. This bias is also reflected on investment levels. Various universities and research centres (e.g., EMBRAPA) are active in this area throughout Brazil [87], at both federal and state levels. For instance, the Agronomic Institute of Paraná (IAPAR) or the Agricultural Research and Rural Extension Company of Santa Catarina (EPAGRI) are among the most prominent. NGOs and social movements are particularly vocal on issues of food and nutritional sovereignty and security, which passes through the production of farmers' own seeds and conservation of landrace germplasms. For example, various governmental, non-governmental and civil society institutions established ReSA (Agroecology Seed Network), an association pushing for peasant autonomy with respect to seed multiplication [88].

\section{Water-Energy-Food (WEF) Considerations}

While extensive literature is available on the water, energy and food implications of sugarcane production - as a result of the heavy political and financial support given to the crop in colonial and modern times-limited empirical knowledge is found on sweet potato or landrace maize. Particularly, when exploring the role of alternative bioenergy crops in sustaining smallholder development, the available literature focuses predominantly on conventional (large-scale) systems [58,89], with limited empirical evidence relating to smallholder production [90]. These knowledge gaps translate into a poor capacity to evaluate the production viability of such crops in smallholder systems, which are 
characterised by low inputs and technology when compared to conventional ones. A consistent ranking of the three study crops in terms of their water needs and calorific outputs cannot be generated due to these knowledge gaps, which require further investigation. Nevertheless, here we have opened the scope to include literature not only related to Brazil, but worldwide. We found that despite being in its infancy, the research on alternative crops is growing. Next, we provide an indicative examination of the water requirements, and potential calorific (energy and/or food) outputs across the three crops based on the limited literature available.

Overall, sweet potato and landrace maize have similar WEF implications. While corn may produce about 2500 L per ha [91], sweet potato, due to its high level of carbohydrate production per unit area [92-94], yields higher levels of ethanol [95]. For instance, in Southern Italy it has been observed a production of $2032 \mathrm{~L} / \mathrm{ha}$ [96], 3320 to $5364 \mathrm{~L} /$ ha in Indonesia [97], 4.17 L/ha in China [98], $4800 \mathrm{~L} / \mathrm{ha}$ in Uruguay [57], and from 6136 to 10,007 L/ha in Central Brazil [99]. Others have reported yields between 2990 and 10,467 L of ethanol per ha [57,100]. These values depend on a range of biological, physiological, physical and chemical processes, which are determined by varying environmental conditions (i.e., climate, soil and water) and genetic factors [101]. Comparatively, sugarcane yields 6000 to $6800 \mathrm{~L}$ of ethanol per ha $[102,103]$.

As regards to water consumption, values for conventional corn grown under agribusiness schemes range between 393 and $735 \mathrm{~mm}$ per crop cycle [104,105]. Values for landrace maize grown by smallholder farmers are not found in the literature, while sweet potato's water consumption accounts for 450 to $500 \mathrm{~mm}$ per cycle [100,106]. Sugarcane has similar food and energy output potential to the other crops, however, the water required to grow it stands out for being notably larger than sweet potato and landrace maize [107]. Moreover, its water consumption value accounts for roughly 1,780 mm per cycle in the state of São Paulo [108]. According to Dias [109], the water demand for sweet potato is about three times lower than that of sugarcane when comparing ethanol productivity with the volume of water consumed during the crop cycle. Once again, local conditions are fundamental for the determination of its productivity and input values. While sweet potato and landrace maize have potential to be produced interchangeably to achieve similar outputs, their suitability under varying contexts will depend on variables, including soil type, the crop variety utilised, the specific weather in the region of study, the climatic conditions during different crop seasons, as well as the specific cost-benefit implications for each crop. It is relevant to note that we do not consider the inputs in terms of labour, energy used in the production and application of fertiliser or energy used in irrigation, as information on these aspects is not currently available.

In the Brazilian context, the country's vast territorial extension results in highly variable agricultural practices subject to different regimes of precipitation and temperature across regions [110]. This has direct implications for the feasibility of growing these three crops for energy and food end uses. One advantage of sweet potato and landrace maize is that, in addition to their lower water requirements, they can be grown across a larger geographical area than sugarcane, thanks to their higher adaptability to varying types of soil and weather $[111,112]$. In terms of sweet potato, it has been highlighted that it has wide adaptation to marginal lands. It can grow under various environments, and is less vulnerable to pest and disease. It is also drought-resistant, has a high multiplication rate and low degeneration of the propagation material, short grow cycle, and can help controlling weed problems and erosion caused by rains. It is responsive to inputs, and its wider harvesting periods make sweet potato popular for peasant subsistence in rural areas [95,113].

The lack of information and knowledge means a multitude of trade-offs remains unexplored. For instance, when valuing the crops' potential and sustainability implications, additional considerations must be made depending on the by-products or waste streams the different crops can generate. As in the case of sugarcane, the disposal of vinasse in soils and water bodies presents numerous challenges and environmental concerns [114]. A comprehensive analysis that considers both positive and negative environmental externalities for the production of each crop is needed in order to allow better prioritisation and evaluation of alternative crops. 
Another trade-off that needs more attention is that while the calorific content of the outputs produced by alternative crops might be similar, this can either be diverted to bioenergy or for food as an end use. In the latter case, food might be intended either for human or animal consumption. Sweet potato tubers are suited to direct human consumption; however, smallholder farmers face difficulties to control the attractiveness (visual aspect and colour) demanded by local markets. Sweet potato stalks and leaves are particularly suited for animal feed in smallholder pig production [115], due to its high-protein content. The dry-milled or starch fractions of landrace maize and sweet potato can be used to produce flour and a range of industrialised food. Sugarcane can be consumed in the form of juice, syrup, dried sugar or molasses, while the sucrose extracted in mills can be used as a raw material in the food industry. Fresh-chopped sugarcane or extracts may be used as a dietary supplement for ruminants or pigs under limited forage availability [116]. Considering this variety of uses, we observe that different sweet potato varieties, as well as sugarcane and corn varieties, may be suited to the production of certain outputs (and related by-products), opening up a wide range of new market opportunities for smallholder farmers. Each component of this multi-faceted system might require varying levels of water inputs and will have varying cost and benefit implications. In terms of sweet potato, researchers have claimed that the diversification and advances in the technology applied to its production have been considerable in the last decades leading to a myriad of opportunities, from energy production to providing raw material for starch, flour, juice, bread, liquors, pigments, candy, and various uses in the cosmetic industry, etc., [117].

In Brazil, the transformation of sweet-potato and landrace maize into energy is modest, with production being used almost entirely for human consumption. Despite that in Brazil the expansion of the formal knowledge-base of the two alternative crops has not been favoured, researchers' calls have started to emerge in terms of the 'attractiveness' of these crops for the biofuel sector $[57,59,60]$. Pilot research units are being run by universities in the states of Rio Grande do Sul and Tocantins. EMBRAPA has specific sweet potato varieties for ethanol production [118], as is the case for varieties developed by the Federal University of Tocantins. Regarding corn cultivation, Brazil already has two large ethanol production units in the State of Mato Grosso and Goiás, according to the National Corn Ethanol Union. However, for the production of landrace maize ethanol, no activities are occurring to the best of our knowledge.

Studies in other parts of the world are growing, and the crops are gaining importance. In recent years, genetic improvement studies delivered varieties of sweet potato-with multiple genotypes identified by Wesley, et al. [99] — that have shown promising potential for their use in various industrialised scenarios.

We acknowledge that each crop and variety therein have their own characteristics, and that production and use need to be adapted to different regions of Brazil (and worldwide), resulting in a variable range of benefits and trade-offs across environmental and socio-economic dimensions. Nevertheless, our analysis of the existing literature suggests that in comparison to sugarcane, sweet potato and landrace maize have a lower environmental impact in terms of water, can be grown in diverse soil types, and also have a greater capacity to resist droughts and plagues. In the face of the current climate change projections, crops with those coping capacities will be more adapted to future climate-related impacts. At the same time, they have the potential to produce energy, higher nutritious food than sugarcane, while opening a window of opportunities to smallholder farmers to participate in new markets. Given the major knowledge gaps identified, empirical investigations into the agronomy and socio-economic implications of sweet potato and landrace maize across smallholder systems are urgently needed to effectively inform production, use and appropriate policy and institutional support for this backbone of the economy. 


\section{Discussion}

Our analysis of the literature has shown that the mass production of biofuel crops in Brazil has been mainly dominated by large farmers and agribusinesses, shaped by international and national policies and institutions. This approach has excluded smallholder farmers, who have not been able to reap development benefits by participating in the biofuel market, thus exacerbating poverty and social inequality [11]. Local policies and institutions designed to stimulate production at smaller quantities or exploring alternative bioethanol crops remain practically non-existent. This highlights a disconnection between the elements of PIK across different scales, which has shaped the types of crops that are produced, having implications for the WEF nexus and the distribution of winners and losers.

The challenge is to achieve a sustainable, socially-just and equitable future, particularly for smallholder farmers who until now have been disfavoured by the prevailing PIK configuration. It is difficult to envisage future opportunities for smallholders to participate in the mainstream sugarcane-based biofuel industry, given prevailing market and production structures. The prioritised production mode has strong equity implications for smallholders as, unlike agribusinesses, they do not have the large amounts of land and high investments required to participate in the market. Without meaningful participation, it will be impossible to achieve all three dimensions of justice and equity. Smallholder farmers' system of collecting and selling alternative crops to the industry is in its infancy. This can represent an important market barrier. However, there are some examples such as PNAE or PLANAPO, which show that well-directed policies can create new markets and open up those opportunities urgently needed for smallholder farmers. Participation underlies distributional justice, as those who participate are more able to define how costs and benefits are distributed, and also recognition, as those who are unable to participate cannot command recognition $[17,119,120]$. However, the two alternative crops that we have analysed, landrace maize and sweet potato, offer the potential for improving development opportunities for smallholders in terms of energy, food sources and market diversification. In diverse regions in Brazil, smallholder farmers have traditionally grown local varieties of these crops, mainly for household consumption [21,121]. Local knowledge about their cultivation and use is abundant, although there has been limited knowledge sharing with other groups $[122,123]$. Sweet potato, particularly cultivated in the northeast of the country, is considered to be relatively easy to grow and has diverse uses, from biofuels and animal feed to the production of paper and cosmetics [124]. In relation to landrace maize, local varieties offer several advantages in terms of sustainability, such as lower production costs, resistance to pests and diseases, and higher resilience to climate variations [125]. The literature examined suggests that sweet potato and landrace maize offer a more accessible and inclusive alternative to smallholder farmers because local knowledge exists, they have similar yields of ethanol per hectare, use less water, and their by-products can be commercialised in various markets (see Section 4). In relation to production costs, for example, Masiero [126] estimated the economic feasibility of using sugarcane, sweet sorghum, cassava, and sweet potato for ethanol production. The author argues that sweet sorghum and sweet potato were the most viable feedstocks. However, further research is required to determine the specific production costs, as well as their related WEF implications.

These alternative crops open up opportunities to diversify economic activities and improve the development situation of small farmers. Sweet potato and landrace maize, especially when managed through sustainable agro-ecological systems, can help to attain food security, as well as to reduce the use of fertilisers, achieve higher productivity rates, prevent soil degradation and offer a clean energy source [127]. In this sense, when managed adequately, they can contribute to some of the Sustainable Development Goals (SDGs), namely, Goal 2 (i.e., ending hunger, achieving food security, improving nutrition and promoting sustainable agriculture), Goal 7 (i.e., ensuring access to affordable, reliable, sustainable and modern energy for all), and Goal 8 (i.e., access to decent work and economic growth).

Promoting better opportunities to achieve equitable and sustainable development based on these crops requires policies and institutions at the local scale, capable of recognising the existing knowledge. The PIK landscape, analysed in Section 3, provided us with a challenging panorama 
for the production of alternative bioenergy crops by smallholder farmers. Policies such RenovaBio, aiming to increase the annual production of ethanol in almost $79 \%$ by 2030 , fail to include the opportunities that alternative crops can bring to Brazil's GHGs mitigation pledges, by focusing only on sugarcane. While large agribusinesses can definitely help to meet those pledges, smallholder farmers can also contribute-considering that smallholder farms account for $84 \%$ of the total farms in Brazil, and provide 70\% of the staple food [128]. Policies and institutions well-directed to expand the production of alternative crops could bring even more benefits in terms of development for millions of families depending on the land in Brazil. For instance, the current programme of PNAE or the Food Acquisition Programme (PPA) promotes decentralised agriculture. Those programmes provide a space for smallholder farmers in the food supply chain, while also improving the nutritional quality of food for local schools. More programmes and new business models that encourage a more equitable production and distribution of the development gains are needed for smallholder farmers. Despite that bioenergy production and consumption could bring benefits in terms of covering the energy needs of smallholders, we identified various barriers that impede further advancements. For example, the current policy landscape prohibits small-scale production, sale and self-consumption of bioenergy by smallholder farmers. One of the major challenges of smallholder farmers is their scale and limited access to resources (financial, technological, market, etc.). Promoting smallholder farmer organisations can help level the playing field and balance structural issues. Collective action can leverage their power by exercising economies of scale $[129,130]$, tackling in this way, their current inability to influence the market, due to their individual size. Local cooperatives, for example, could be crucial to organise these efforts, as they have a history of producing social and political transformations [131]. Cooperatives can give representation to smallholders, important for the recognition and participation dimensions of social justice and can leverage collective efforts to produce better outcomes. Smallholders could be incentivised in the production of biofuels given the possibility of producing ethanol derived from sweet potato and landrace maize in small distilleries as long as they are supported by well-organised cooperatives [103].

Cross-fertilisation of policies that have helped in the past to reach smallholder farmers could be valuable to expand instruments, such as 'Etanol Verde', to smallholders to ensure sustainability in the production of alternative crops. Historically, those instruments have been targeted for large-scale producers, but adopting standards and certifications by smallholders is an inevitable process and a positive trajectory of sustainable development for the biofuel industry [132]. However, research has also highlighted that certification schemes can have high barriers to participation, meaning that only already commercially minded farmers can benefit [132]. This can be overcome by ensuring that certification schemes have equity and justice considerations built-in, and that these are compulsory rather than voluntary. In addition, barriers to participation can be minimised by including training and capacity building for resource-poor smallholder farmers [133]. For instance, the voluntary regulatory instrument of organic certification, PLANAPO, has been successful with smallholder farmers in Parana, or PNATER, which supports agroecological training and exchange of experiences [69]. The Social Fuel Certificate (Selo Combustível Social), granted by the Ministry of Agriculture [134], is another pertinent example, which inserts family agriculture, via registered cooperatives, into the biodiesel production chain. Additional criteria for the certificate have been officially approved this year, permitting large biodiesel producers to acquire a certain percentage of their inputs from these cooperatives (at least $60 \%$ of their members need to be family farmers), thus, obtaining the designation of producers of 'social fuel'.

These policies can be used as platforms to extend technical support and help smallholder farmers to advance towards a more sustainable bioenergy production. There is a need to strengthen current programmes, which have smallholder farmers at their core. PRONAF, for example, needs to expand its risk management rules to include alternative crops. This is important because it could assist smallholder farmers by expanding the availability of credit and insurance cover. Currently, alternative crops are not included in official studies of climatic risk zoning; thus, smallholder farmers cannot 
report the use of other crops and are left without support if their crops fail. PRONAF provides an opportunity to incorporate smallholder farmers' informal knowledge to inform the guidelines of the Agricultural Climate Risk Zoning provisions and, in this way, expand the use of alternative crops. This is also an example of how the sharing of informal knowledge into documents and processes dominated by formal knowledge could benefit smallholder farmers.

Universities have an important role to play in moving towards knowledge co-production with multiple stakeholder groups. Our review shows that while research on sugarcane has been heavily supported by universities, this has not been the case for sweet potato nor landrace maize. In addition, research has been concentrated in particular areas, such as Sao Paulo, leaving behind smaller universities across Brazil. Reallocation and redistribution of research funds need urgent attention [85]. Local universities, through their rural extensions and partnerships, are well placed to make the link between research institutes, government, and smallholder farmers. Universities and research centres could help address remaining knowledge gaps by conducting more research on the WEF requirements of sweet potato and landrace maize, as well as of other alternative crops, in addition to carrying out detailed cost-benefit and environmental impact studies in order to assess the technical, socio-economic and operational feasibility of using them to produce bioenergy. Assessing optimal crop rotation is another relevant issue in order to identify adequate varieties and crop types that can help to maximise soil fertility and plant nutrition.

While the previous examples show positive perspectives, given the current political circumstances in Brazil, the formulation of policies towards improving smallholder farmers' conditions, however, faces difficulties. The inauguration of Brazil's new government in 2019 has led to a 'systematic dismantling' of Brazilian environmental laws, weakening environmental enforcement and institutions and increasing the risks of incurring losses on all fronts [135-137]. In the case of smallholder farmers, for instance, the restructuring of the Ministry of Environment and the appointment of new ministers, including in the Ministry of Agriculture [138], or the law proposal No. 5695 to end the government obligation to buy $30 \%$ of the food that smallholders produce [139], have both reinforced concerns that the focus on large agribusinesses will persist. Among the situations that give rise to concern are presidential decrees that have excluded advisory councils representing smallholder farming, as well as changing the number of questions in the agricultural census, making it difficult to stratify and clearly define the peasant agriculture class. The way the Brazilian state has prioritised policies, knowledge, institutions through time has created trade-offs affecting issues of social justice, such as recognition justice and participation justice for smallholder farmers. By the same token, the decisions of the State government have shaped aspects of water, energy and food through time. The perspectives of those essential resources in Brazil are worrisome as the recent policies implemented have disturbed the key role the country had pursued on climate change mitigation and sustainable development efforts [140]. The current political context in the country may worsen the scenario [141], leading to a fear of state action limiting, and in some cases, threatening the activities of researchers, educators, and environmental practitioners-which has been described as the "landscape of fear" [142].

Given the political situation and that smallholder farmers have been historically marginalised from the benefits of bioenergy production, we argue that it is essential to promote local genetic improvement, selecting varieties adapted to each cultivation region and to adopt agronomic management systems. It is also important to stimulate research aimed at simplifying the processes of transformation of biomass (sweet potato, landrace maize, sorghum, among others) in the context of small and medium scale ethanol production. Moreover, more flexibility in federal legislation is needed, allowing the direct sale of ethanol to the final consumer, which would make several small and medium scale processing plants financially viable, in order to improve the welfare of smallholders. 


\section{Conclusions}

This paper has examined the literature to unpack the relationships within and between WEF and PIK, which traverse multiple spatial and temporal scales. PIK vary widely across local, regional, national and international levels. Mass production of biofuels in Brazil has been largely shaped and supported by international and national policies and institutions through time. This is reflected in the large volumes of ethanol produced by large agribusinesses mainly from sugarcane. When it comes to the local scale, and the smallholder farmers, local policies and institutions remain practically non-existent and have barely played a role in stimulating biofuel production in smaller quantities or exploring alternative biofuel crops. Local knowledge is abundant, but in most cases has been often ignored or scarcely disseminated. This highlights an opportunity for the "share" aspect of the WEF-PIK framework, which should be emphasised in addressing the disconnection between PIK across scales and levels. Not least to enable smallholders to play a greater role in determining the types of crops that are produced and supported, with subsequent impacts on WEF in terms of energy and food consumption and mainly water use. The examined alternative crops to sugarcane, i.e., sweet potato and landrace maize, show potential benefits for the smallholder farmer because there is local traditional knowledge of them, the alternative crops have multiple uses which can fulfil multiple smallholder needs-e.g., fuel, animal feed,-and generate diversified sources of income generation-through the by-products, for instance. The benefits seem more evident as regards the water consumption dimension, as their water input requirements stand out for being notably smaller than the mainstream one. Crops that have less of an impact on the environment, and that are more resistant to pests and weather-related impacts, seem promising-but empirical evidence on alternative crops is very limited, and more research is required to unveil the detailed benefits and trade-offs.

The WEF and PIK nexuses, and their inherent inter- and intra-relationships, are not static, but continue changing and evolving over time. The challenge for Brazil is to achieve a sustainable, socially-just and equitable future, particularly for smallholder farmers who until now have been disfavoured by the prevailing PIK configuration, while the large agribusinesses have accumulated the gains. In this sense, it is vital to address the PIK disconnection through improved consideration of recognition and participation justice supported by improved knowledge across scales and stakeholder groups.

Author Contributions: The paper was conceptualised by P.S., S.A., N.F., L.C.S. and M.S. Relevant literature and documents were identified by P.S., S.A., N.F., and M.S. The review was conducted by P.S., S.A., N.F., C.W., P.H.W.N., C.H.R., J.A.G., and N.M.d.S. The four latter authors provided expert input. P.S., S.A., N.F., L.C.S., C.W. and M.S. wrote the manuscript. N.A. developed the figure. All authors reviewed, commented and edited various drafts. All authors have read and agreed to the published version of the manuscript.

Funding: This research was funded by the British Council, grant number 332400014. P.S. also acknowledges funding by the UKRI Economics and Social Research Council, grant number ES/S001727/1. L.C.S. is a Royal Society Wolfson Research Merit Award holder. M.S. was supported by the UKRI Engineering and Physical Sciences Research Council (EPSRC) for the UK Centre for Research into Energy Demand Solutions (CREDS), grant reference EP/R035288/1, and the UK Energy Research Centre (UKERC) Phase 4, under award EP/S029575/1. P.H.W.N., C.H.R., J.A.G. and N.M.d.S. also acknowledge funding by Fundação Araucária, grant number 48859.521.33708.08122017.

Acknowledgments: We appreciate the input from three anonymous reviewers who contributed to improve the quality of this paper.

Conflicts of Interest: The authors declare no conflict of interest. The funders had no role in the design of the study; in the collection, analyses, or interpretation of data; in the writing of the manuscript, or in the decision to publish the results.

\section{References}

1. Wiggins, S.; Kirsten, J.; Llambi, L. The future of small farms. World Dev. 2010, 38, 1341-1348. [CrossRef]

2. Lowder, S.K.; Skoet, J.; Raney, T. The number, size, and distribution of farms, smallholder farms, and family farms worldwide. World Dev. 2016, 87, 16-29. [CrossRef] 
3. Altieri, A.M.; Koohafkan, P. Enduring Farms: Climate Change, Smallholders and Traditional Farming Communities; Third World Network: Penang, Malaysia, 2008.

4. Stringer, L.C.; Fraser, E.D.G.; Harris, D.; Lyon, C.; Pereira, L.; Ward, C.F.M.; Simelton, E. Adaptation and development pathways for different types of farmers. Environ. Sci. Policy 2020, 104, 174-189. [CrossRef]

5. Dorward, A.; Anderson, S.; Bernal, Y.N.; Vera, E.S.; Rushton, J.; Pattison, J.; Paz, R. Hanging in, stepping up and stepping out: Livelihood aspirations and strategies of the poor. Dev. Pract. 2009, 19, 240-247. [CrossRef]

6. Lei $n^{\circ}$ 11.326, de 24 de julho de 2006. Presidência da República, C.C., Subchefia para Assuntos Jurídicos (Ed.) 2006. Available online: http://www.planalto.gov.br/ccivil_03/_Ato2004-2006/2006/Lei/L11326.htm (accessed on 5 March 2020).

7. Embrapa. Módulos fiscais. Available online: https://www.embrapa.br/codigo-florestal/area-de-reservalegal-arl/modulo-fiscal (accessed on 29 February 2020).

8. Ejigu, M. Toward energy and livelihoods security in africa: Smallholder production and processing of bioenergy as a strategy. Nat. Resour. Forum 2008, 32, 152-162. [CrossRef]

9. Vermeulen, S.; Goad, N. Towards Better Practice in Smallholder Palm Oil Production; International Institute for Environment and Development (IIED): London, UK, 2006.

10. Dubois, O. Making sure that biofuel development benefits small farmers and communities. Unasylva 2008, 59, 25-32.

11. Hall, J.; Matos, S.; Severino, L.; Beltrao, N. Brazilian biofuels and social exclusion: Established and concentrated ethanol versus emerging and dispersed biodiesel. J. Clean. Prod. 2009, 17, S77-S85. [CrossRef]

12. Afionis, S. Brazil's Ethanol Fuel Program; Lap Lambert Academic Publishing: Köln, Germany, 2009.

13. Moraes, M.A.F.D.; Oliveira, F.C.R.; Diaz-Chavez, R.A. Socio-economic impacts of brazilian sugarcane industry. Environ. Dev. 2015, 16, 31-43. [CrossRef]

14. Blaber-Wegg, T.; Hodbod, J.; Tomei, J. Incorporating equity into sustainability assessments of biofuels. Curr. Opin. Environ. Sustain. 2015, 14, 180-186. [CrossRef]

15. Creutzig, F.; Corbera, E.; Bolwig, S.; Hunsberger, C. Integrating place-specific livelihood and equity outcomes into global assessments of bioenergy deployment. Environ. Res. Lett. 2013, 8, 11. [CrossRef]

16. Leck, H.; Conway, D.; Bradshaw, M.; Rees, J. Tracing the water-energy-food nexus: Description, theory and practice. Geogr. Compass 2015, 9, 445-460. [CrossRef]

17. Wood, B.T.; Stringer, L.C.; Dougill, A.J.; Quinn, C.H. Socially just triple-wins? A framework for evaluating the social justice implications of climate compatible development. Sustainability 2018, 10, 211. [CrossRef]

18. Sawyer, A.; Staley, C.; Lamb, J.; Sheaffer, C.; Kaiser, T.; Gutknecht, J.; Sadowsky, M.J.; Rosen, C. Cultivar and phosphorus effects on switchgrass yield and rhizosphere microbial diversity. Appl. Microbiol. Biotechnol. 2019, 103, 1973-1987. [CrossRef] [PubMed]

19. Widodo, Y.; Wahyuningsih, S.; Ueda, A. Sweet potato production for bio-ethanol and food related industry in indonesia: Challenges for sustainability. Procedia Chem. 2015, 14, 493-500. [CrossRef]

20. Cantos-Lopes, A.; Vilela-de Resende, J.T.; Machado, J.; Perez-Guerra, E.; Vilela-Resende, N. Alcohol production from sweet potato (ipomoea batatas (1.) lam.) genotypes in fermentative medium. Acta Agronómica 2018, 67, 231-237. [CrossRef]

21. Rebollar, P.B.M.; Miller, P.R.M.; Carmo, V.B. Desenvolvimento rural e práticas tradicionais de agricultores familiares: O caso do milho no vale do capivari, santa catarina, brasil. Rev. Bras. De Agroecol. 2010, 5, 174-186.

22. Wagner, S.A.; Marques, F.C.; Menasche, R. Agricultura familiar à mesa. In Agricultura familiar à mesa: Saberes e práticas da alimentação no vale do taquari; Menasche, R., Ed.; UFRGS Editora: Rio Grande do Sul, Brazil, 2007; pp. 58-77.

23. Stringer, L.C.; Quinn, C.H.; Le, H.T.V.; Msuya, F.; Pezzuti, J.; Dallimer, M.; Afionis, S.; Berman, R.; Orchard, S.E.; Rijal, M.L. A new framework to enable equitable outcomes: Resilience and nexus approaches combined. Earth Future 2018, 6, 902-918. [CrossRef]

24. McDermott, M.; Mahanty, S.; Schreckenberg, K. Examining equity: A multidimensional framework for assessing equity in payments for ecosystem services. Environ. Sci. Policy 2013, 33, 416-427. [CrossRef]

25. Schlosberg, D. Reconceiving environmental justice: Global movements and political theories. Environ. Politics 2004, 13, 517-540. [CrossRef]

26. Bennett, N.J. Using perceptions as evidence to improve conservation and environmental management. Conserv. Biol. 2016, 30, 582-592. [CrossRef] 
27. Halpern, B.S.; Klein, C.J.; Brown, C.J.; Beger, M.; Grantham, H.S.; Mangubhai, S.; Ruckelshaus, M.; Tulloch, V.J.; Watts, M.; White, C.; et al. Achieving the triple bottom line in the face of inherent trade-offs among social equity, economic return, and conservation. Proc. Natl. Acad. Sci. USA 2013, 110, 6229-6234. [CrossRef] [PubMed]

28. Middleton, C.; Allouche, J.; Gyawali, D.; Allen, S. The rise and implications of the water-energy-food nexus in southeast asia through an environmental justice lens. Water Altern. 2015, 8, 627-654.

29. Agarwal, B. Food sovereignty, food security and democratic choice: Critical contradictions, difficult conciliations. J. Peasant Stud. 2014, 41, 1247-1268. [CrossRef]

30. Franco, J.; Feodoroff, T.; Kay, S.; Kishimoto, S.; Pracucci, G.; Santos, R. The global water grab: A primer; Transnational Institute for Hands off the Land Alliance: Amsterdam, The Netherlands, 2014; pp. 1-40.

31. Hildyard, N.; Lohmann, L.; Sexton, S. Energy security for what? For whom? The Corner House: Dorset, UK, 2012.

32. Stringer, L.C.; Reed, M.S.; Fleskens, L.; Thomas, R.J.; Le, Q.B.; Lala-Pritchard, T. A new dryland development paradigm grounded in empirical analysis of dryland systems science. Land Degrad. Dev. 2017, 28, $1952-1961$. [CrossRef]

33. Levy, Y.; Ellis, T.J. A systems approach to conduct an effective literature review in support of information systems research. Inf. Sci.: Int. J. Emerg. Transdiscipl. 2006, 9, 181-212. [CrossRef]

34. Sylvester, A.; Tate, M.; Johnstone, D. Beyond synthesis: Re-presenting heterogeneous research literature. Behav. Inf. Technol. 2013, 32, 1199-1215. [CrossRef]

35. Afionis, S.; Stringer, L.C. European union leadership in biofuels regulation: Europe as a normative power? J. Clean Prod. 2012, 32, 114-123. [CrossRef]

36. Pilgrim, S.; Harvey, M. Battles over biofuels in europe: Ngos and the politics of markets. Sociol. Res. Online 2010, 15, 16. [CrossRef]

37. Ponte, S. The evolutionary dynamics of biofuel value chains: From unipolar and government-driven to multipolar governance. Environ. Plan. A - Econ. Space 2014, 46, 353-372. [CrossRef]

38. Lima, M.G.B.; Gupta, J. The policy context of biofuels: A case of non-governance at the global level? Glob. Environ. Politics 2013, 13, 46-64. [CrossRef]

39. Rosillo-Calle, F.; Cortez, L.A.B. Towards proalcool ii - a review of the brazilian bioethanol programme. Biomass Bioenerg. 1998, 14, 115-124. [CrossRef]

40. Stattman, S.L.; Hospes, O.; Mol, A.P.J. Governing biofuels in brazil: A comparison of ethanol and biodiesel policies. Energy Policy 2013, 61, 22-30. [CrossRef]

41. Marcossi, G.P.C.; Moreno-Perez, O.M. A closer look at the brazilian social fuel seal: Uptake, operation and dysfunctions. Biofuels-Uk 2018, 9, 429-439. [CrossRef]

42. Wilkinson, J.; Herrera, S. Biofuels in brazil: Debates and impacts. J. Peasant Stud. 2010, 37, 749-768. [CrossRef]

43. La Rovere, E.L.; Pereira, A.S.; Simoes, A.F. Biofuels and sustainable energy development in brazil. World Dev. 2011, 39, 1026-1036. [CrossRef]

44. Ferreira, M.P.; Alves, D.S.; Shimabukuro, Y.E. Forest dynamics and land-use transitions in the brazilian atlantic forest: The case of sugarcane expansion. Reg. Environ. Chang. 2015, 15, 365-377. [CrossRef]

45. Scarpare, F.V.; Hernandes, T.A.D.; Ruiz-Correa, S.T.; Kolln, O.T.; Gava, G.; dos Santos, L.N.S.; Victoria, R.L. Sugarcane water footprint under different management practices in brazil: Tiete/jacare watershed assessment. J. Clean. Prod. 2016, 112, 4576-4584. [CrossRef]

46. Mercure, J.F.; Paim, M.A.; Bocquillon, P.; Lindner, S.; Salas, P.; Martinelli, P.; Berchin, I.I.; Guerra, J.; Derani, C.; de Albuquerque, C.L.; et al. System complexity and policy integration challenges: The brazilian energy-water-food nexus. Renew. Sustain. Energy Rev. 2019, 105, 230-243. [CrossRef]

47. Benites-Lazaro, L.L.; Giatti, L.; Giarolla, A. Sustainability and governance of sugarcane ethanol companies in brazil: Topic modeling analysis of csr reporting. J. Clean Prod. 2018, 197, 583-591. [CrossRef]

48. Taniwaki, R.H.; Forte, Y.A.; Silva, G.O.; Brancalion, P.H.S.; Cogueto, C.V.; Filoso, S.; Ferraz, S.F.B. The native vegetation protection law of brazil and the challenge for first-order stream conservation. Perspect. Ecol. Conserv. 2018, 16, 49-53. [CrossRef]

49. Filoso, S.; do Carmo, J.B.; Mardegan, S.F.; Lins, S.R.M.; Gomes, T.F.; Martinelli, L.A. Reassessing the environmental impacts of sugarcane ethanol production in brazil to help meet sustainability goals. Renew. Sustain. Energy Rev. 2015, 52, 1847-1856. [CrossRef] 
50. Nogueira, L.A.H.; Capaz, R.S. Biofuels in brazil: Evolution, achievements and perspectives on food security. Glob. Food Secur. -Agric. Policy Econ. Environ. 2013, 2, 117-125. [CrossRef]

51. Schaffel, S.B.; La Rovere, E.L. The quest for eco-social efficiency in biofuels production in brazil. J. Clean Prod. 2010, 18, 1663-1670. [CrossRef]

52. UNFCCC. Intended Nationally Determined Contribution towards Achieving the Objective of the United Nations Framework Convention on Climate Change; Federative Republic Of Brazil: Brasilia, Brazil, 2015.

53. Grassi, M.C.B.; Pereira, G.A.G. Energy-cane and renovabio: Brazilian vectors to boost the development of biofuels. Ind. Crop. Prod. 2019, 129, 201-205. [CrossRef]

54. Bordonal, R.D.; Carvalho, J.L.N.; Lal, R.; de Figueiredo, E.B.; de Oliveira, B.G.; La Scala, N. Sustainability of sugarcane production in brazil. A review. Agron. Sustain. Dev. 2018, 38, 23. [CrossRef]

55. Petrini, M.A.; Rocha, J.V.; Brown, J.C.; Bispo, R.C. Using an analytic hierarchy process approach to prioritize public policies addressing family farming in brazil. Land Use Pol. 2016, 51, 85-94. [CrossRef]

56. Rocha, C.; Burlandy, L.; Maluf, R. Small farms and sustainable rural development for food security: The brazilian experience. Dev. S. Afr. 2012, 29, 519-529. [CrossRef]

57. Lareo, C.; Ferrari, M.D.; Guigou, M.; Fajardo, L.; Larnaudie, V.; Ramirez, M.B.; Martinez-Garreiro, J. Evaluation of sweet potato for fuel bioethanol production: Hydrolysis and fermentation. Springerplus 2013, 2, 11. [CrossRef]

58. Zhang, J.; Jia, C.R.; Wu, Y.; Xia, X.F.; Xi, B.D.; Wang, L.J.; Zhai, Y.L. Life cycle energy efficiency and environmental impact assessment of bioethanol production from sweet potato based on different production modes. PLoS One 2017, 12, 12. [CrossRef]

59. Eckert, C.T.; Frigo, E.P.; Albrecht, L.P.; Albrecht, A.J.P.; Christ, D.; Santos, W.G.; Berkembrock, E.; Egewarth, V.A. Maize ethanol production in brazil: Characteristics and perspectives. Renew. Sustain. Energy Rev. 2018, 82, 3907-3912. [CrossRef]

60. Silva, J.O.V.E.; Almeida, M.F.; Alvim-Ferraz, M.D.; Dias, J.M. Integrated production of biodiesel and bioethanol from sweet potato. Renew. Energy 2018, 124, 114-120. [CrossRef]

61. Zhang, P.; Chen, C.; Shen, Y.; Ding, T.; Ma, D.; Hua, Z.; Sun, D. Starch saccharification and fermentation of uncooked sweet potato roots for fuel ethanol production. Bioresour. Technol. 2013, 128, 835-838. [CrossRef] [PubMed]

62. Matei, A.P.; Swagemakers, P.; Garcia, M.D.D.; da Silva, L.X.; Ventura, F.; Milone, P. State support in brazil for a local turn to food. Agriculture-Basel 2017, 7, 5. [CrossRef]

63. BCB. Programa nacional de fortalecimento da agricultura familiar-Pronaf; Banco Central do Brasil: Brasilia, Brazil, 2017.

64. Gazolla, M.; Schneider, S. What is "strengthening" the family farm? An analysis of pronaf credit costs and investment in rio grande do sul. Rev. De Econ. E Sociol. Rural 2013, 51, 45-68. [CrossRef]

65. Embrapa. Agroecological Zoning. Available online: https://www.embrapa.br/en/tema-zoneamentoagroecologico/nota-tecnica (accessed on 21 November 2019).

66. Batista, H.R.; Neder, H.D. Efeitos do pronaf sobre a pobreza rural no brasil (2001-2009). Rev. De Econ. E Sociol. Rural 2014, 52, 147-166. [CrossRef]

67. Grisa, C.; Wesz Junior, V.J.; Buchweitz, V.D. Revisitando o pronaf: Velhos questionamentos, novas interpretações. Rev. Econ. E Sociol. Rural 2014, 52, 323-346. [CrossRef]

68. Valencia, V.; Wittman, H.; Blesh, J. Structuring markets for resilient farming systems. Agron. Sustain. Dev. 2019, 39, 14. [CrossRef]

69. Giraldo, O.F.; McCune, N. Can the state take agroecology to scale? Public policy experiences in agroecological territorialization from latin america. Agroecol. Sustain. Food Syst. 2019, 43, 785-809. [CrossRef]

70. Da Silva, H.B.C.; Cavalcanti, D.C.; Pedroso, A.F. Pesquisa e Extensão Para a Agricultura Familiar no Âmbito da Politica Nacional de Assistência Técnica e Extensão Rural; MDA: Brasilia, Brazil, 2015.

71. Morgera, E.; Kati, K.; Ambra, G. Case studies on bioenergy policy and law: Options for sustainability; FAO Legislative Study: Rome, Italy, 2009.

72. Hall, J.; Matos, S.; Silvestre, B.; Martin, M. Managing technological and social uncertainties of innovation: The evolution of brazilian energy and agriculture. Technol. Forecast. Soc. Chang. 2011, 78, 1147-1157. [CrossRef]

73. Furtado, A.T.; Scandiffio, M.I.G.; Cortez, L.A.B. The brazilian sugarcane innovation system. Energy Policy 2011, 39, 156-166. [CrossRef] 
74. Martinelli, L.A.; Filoso, S. Expansion of sugarcane ethanol production in brazil: Environmental and social challenges. Ecol. Appl. 2008, 18, 885-898. [CrossRef] [PubMed]

75. Mendonça, M.L. Monocropping for agrofuels: The case of brazil. Development 2011, 54, 98-103. [CrossRef]

76. Spetic, W.; Marquez, P.; Kozak, R. Critical areas and entry points for sustainability-related strategies in the sugarcane-based ethanol industry of brazil. Bus. Strategy Environ. 2012, 21, 370-386. [CrossRef]

77. Ghinoi, S.; Wesz, V.J.; Piras, S. Political debates and agricultural policies: Discourse coalitions behind the creation of brazil's pronaf. Land Use Policy 2018, 76, 68-80. [CrossRef]

78. Sidaner, E.; Balaban, D.; Burlandy, L. The brazilian school feeding programme: An example of an integrated programme in support of food and nutrition security. Public Health Nutr. 2013, 16, 989-994. [CrossRef] [PubMed]

79. Diesel, V.; Dias, M.M. The brazilian experience with agroecological extension: A critical analysis of reform in a pluralistic extension system. J. Agric. Educ. Ext. 2016, 22, 415-433. [CrossRef]

80. Schenini, P.C.; Pinheiro, A.M.; Zanella, L.C.H.; Da Silva, F.A.; Costa, A.M. Cooperativas de produção agropecuária do mst: Possibilidades e limites como indutora da sustentabilidade dos assentamentos. In 44th Congress, 23-27 July 2006; Sociedade Brasileira de Economia, Administracao e Sociologia Rural (SOBER): Fortaleza, Brazil, 2006.

81. Etzkowitz, H.; Leydesdorff, L. The dynamics of innovation: From national systems and "mode 2" to a triple helix of university-industry-government relations. Res. Policy 2000, 29, 109-123. [CrossRef]

82. Kaup, F. The Sugarcane Complex in Brazil: The Role of Innovation in a Dynamic Sector on Its Path towards Sustainability; Springer: Berlin/Heidelberg, Germany, 2015; p. 304.

83. Selfa, T.; Bain, C.; Moreno, R.; Eastmond, A.; Sweitz, S.; Bailey, C.; Pereira, G.S.; Souza, T.; Medeiros, R. Interrogating social sustainability in the biofuels sector in latin america: Tensions between global standards and local experiences in mexico, brazil, and colombia. Environ. Manage. 2015, 56, 1315-1329. [CrossRef] [PubMed]

84. Embrapa. Como plantar batata-doce. Available online: https://www.embrapa.br/hortalicas/como-plantarbatata-doce (accessed on 5 March 2020).

85. Manners, R.; van Etten, J. Are agricultural researchers working on the right crops to enable food and nutrition security under future climates? Glob. Environ. Chang. 2018, 53, 182-194. [CrossRef]

86. CIP. Annual Report 2017: Harnessing Potato and Sweetpotato's Power for Food Security, Nutrition and Climate Resilience; International Potato Center (Centro Internacional de la Papa): Lima, Peru, 2017.

87. Teixeira, F.F.; Costa, F.M. Caracterização de Recursos Genéticos de Milho; Embrapa: Brasilia, Brazil, 2010.

88. Passos, M.; Fabro, J.; Bittencourt, N.; Jantara, A.; Seixas, C.; Rocha, J.; Alves, R.; Licheski, J.L.; Corbari, T.L.; Rinklin, J.G. A Rede Sementes da Agroecologia no Paraná (ReSA). In Proceedings of the Conservação e manejo da sociobiodiversidade e direitos dos agricultores e povos e comunidades tradicionais, Congresso Brasileiro e Latino-americano de Agroecologia 2017, Brasília, Brazil, 12-15 September 2017.

89. Bellezoni, R.A.; Sharma, D.; Villela, A.A.; Pereira, A.O. Water-energy-food nexus of sugarcane ethanol production in the state of goias, brazil: An analysis with regional input-output matrix. Biomass Bioenerg. 2018, 115, 108-119. [CrossRef]

90. Van Vugt, D.; Franke, A.C. Exploring the yield gap of orange-fleshed sweet potato varieties on smallholder farmers' fields in malawi. Field Crop. Res. 2018, 221, 245-256. [CrossRef]

91. Manochio, C.; Andrade, B.R.; Rodriguez, R.P.; Moraes, B.S. Ethanol from biomass: A comparative overview. Renew. Sustain. Energy Rev. 2017, 80, 743-755. [CrossRef]

92. Ziska, L.H.; Runion, G.B.; Tomecek, M.; Prior, S.A.; Torbet, H.A.; Sicher, R. An evaluation of cassava, sweet potato and field corn as potential carbohydrate sources for bioethanol production in alabama and maryland. Biomass Bioenergy 2009, 33, 1503-1508. [CrossRef]

93. Zhang, L.; Zhao, H.; Gan, M.; Jin, Y.; Gao, X.; Chen, Q.; Guan, J.; Wang, Z. Application of simultaneous saccharification and fermentation (ssf) from viscosity reducing of raw sweet potato for bioethanol production at laboratory, pilot and industrial scales. Bioresour. Technol. 2011, 102, 4573-4579. [CrossRef]

94. Lee, W.-S.; Chen, I.C.; Chang, C.-H.; Yang, S.-S. Bioethanol production from sweet potato by co-immobilization of saccharolytic molds and saccharomyces cerevisiae. Renew. Energy 2012, 39, 216-222. [CrossRef]

95. Duvernay, W.H.; Chinn, M.S.; Yencho, G.C. Hydrolysis and fermentation of sweetpotatoes for production of fermentable sugars and ethanol. Ind. Crop. Prod. 2013, 42, 527-537. [CrossRef] 
96. Montefusco, A.; Durante, M.; Grassi, S.; Piro, G.; Dalessandro, G.; Lenucci, M.S. Assessment of sweet potato [ipomoea batatas (1.) lam] for bioethanol production in southern italy. Plant Biosyst. Int. J. Deal. All Asp. Plant Biol. 2014, 148, 1117-1126. [CrossRef]

97. Waluyo, B.; Roosda, A.A.; Istifadah, N.; Ruswandi, D.; Karuniawan, A. Identification of fifty sweetpotato (ipomoea batatas (1.) lam.) promising clones for bioethanol raw materials. Energy Procedia 2015, 65, $22-28$. [CrossRef]

98. Jin, Y.; Fang, Y.; Zhang, G.; Zhou, L.; Zhao, H. Comparison of ethanol production performance in 10 varieties of sweet potato at different growth stages. Acta Oecologica 2012, 44, 33-37. [CrossRef]

99. Wesley, R.d.S.; Paradiso Martins, L.; Antônio da Silveira, M.; Ferreira dos Santos, W.; Cavalvante Gonçalves, R.; Rodrigues de Souza, F.; Raquel dos Resplandes, G.S.; da Mata Lima, M. Identificação agronômica de genótipos de batata-doce em banco de germoplasma para fins industriais de etanol carburante. Technol. Cien. Agropec. $2013,7,31-34$.

100. Silveira, M.A.d.; Souza, F.R.d.; Alvim, T.d.C.; Dias, L.E.; Santana, W.R.; Vital, M.d.K.G.S.; Gouvêa, G.R.d.S.R.; Costa, D.M.d. A cultura da batata-doce como fonte de matéria prima para produção de etanol. In Boletim Técnico; Equipe de Apoio Técnico-Laboratório de Sistemas de Produção de Energia a Partir de Fontes Renováveis-LASPER/UFT; UFT: Palmas, Brazil, 2007.

101. Doorenbos, J.; Kassam, A.H.; Bentvelsen, C.I.M. Yield Response to Water; Food and Agriculture Organization of the United Nations: Rome, Italy, 1979; pp. 1-193.

102. Soccol, C.R.; Vandenberghe, L.P.d.S.; Medeiros, A.B.P.; Karp, S.G.; Buckeridge, M.; Ramos, L.P.; Pitarelo, A.P.; Ferreira-Leitão, V.; Gottschalk, L.M.F.; Ferrara, M.A.; et al. Bioethanol from lignocelluloses: Status and perspectives in brazil. Bioresour. Technol. 2010, 101, 4820-4825. [CrossRef] [PubMed]

103. Kohlhepp, G. Análise da situação da produção de etanol e biodiesel no brasil. Estud. Avançados 2010, 24, 223-253. [CrossRef]

104. Köpp, L.M.; Peiter, M.X.; Ben, L.H.B.; Nogueira, H.M.C.M.; Padrón, R.A.R.; Robaina, A.D.; Buske, T.C. Simulação da necessidade hídrica e estimativa de produtividade para cultura do milho em municípios do rs. Rev. Bras. De Milho E Sorgo 2015, 14, 235-246. [CrossRef]

105. Bergamaschi, H.; Antonio Dalmago, G.; Comiran, F.; Ito Bergonci, J.; Gustavo Müller, A.; França, S.; Odair Santos, A.; Radin, B.; Adriane Menegassi Bianchi, C.; Gabert Pereira, P. Deficit hídrico e produtividade na cultura do milho. Pesq. Agropec. Bras. 2006, 41, 243-249. [CrossRef]

106. Mantovani, E.C.; Delazari, F.T.; Dias, L.E.; de Assis, I.R.; Vieira, G.H.S.; Landim, F.M. Eficiência no uso da água de duas cultivares de batata-doce em resposta a diferentes lâminas de irrigação. Hortic. Bras. 2013, 31, 602-606. [CrossRef]

107. Carr, M.K.V.; Knox, J.W. The water relations and irrigation requirements of sugar cane (saccharum officinarum): A review. Exp. Agric. 2011, 47, 1-25. [CrossRef]

108. Silva, V.P.R.; Borjes, C.J.R.; Albuquerque, W.G. Necessidades hídricas da cana-de-açúcar cultivada em clima tropical water requirements of sugar cane grown in tropical environment. Ciências Agrárias 2014, 35, 625-632. [CrossRef]

109. Dias, L. Culturas bioenergéticas para a produção de etanol; Boletim Informativo da Sociedade Brasileira de Ciência do Solo: Viçosa-MG, Brazil, 2010; pp. 10-15.

110. Sentelhas, P.C.; Monteiro, J.E.B.A. Agrometeorologia dos cultivos: Informaçoes para uma agricultura sustentável. In Agrometeorología dos cultivos. O fator meteorológico na produção agrícola; Monteiro, J.E.B.A., Ed.; Inmet: Brasilia, Brazil, 2009; pp. 3-12.

111. Bagley, J.E.; Davis, S.C.; Georgescu, M.; Hussain, M.Z.; Miller, J.; Nesbitt, S.W.; VanLoocke, A.; Bernacchi, C.J. The biophysical link between climate, water, and vegetation in bioenergy agro-ecosystems. Biomass Bioenergy 2014, 71, 187-201. [CrossRef]

112. De Castro, L.A.S.; Treptow, R.; Becker, A. Potencialidade da cultivar de batata-doce brs-cuia como matéria prima para a produção de etanol. In Simpósio Estadual de Agroenergia, IV Reunião Técnica de Agroenergia - RS; Embrapa: Porto Alegre RS, Brasil, 2012.

113. Cao, Y.; Tian, H.; Yao, K.; Yuan, Y. Simultaneous saccharification and fermentation of sweet potato powder for the production of ethanol under conditions of very high gravity. Front. Chem. Sci. Eng. 2011, 5, 318-324. [CrossRef]

114. Christofoletti, C.A.; Escher, J.P.; Correia, J.E.; Marinho, J.F.U.; Fontanetti, C.S. Sugarcane vinasse: Environmental implications of its use. Waste Manag. 2013, 33, 2752-2761. [CrossRef] 
115. Ncobela, C.N.; Kanengoni, A.T.; Hlatini, V.A.; Thomas, R.S.; Chimonyo, M. A review of the utility of potato by-products as a feed resource for smallholder pig production. Anim. Feed Sci. Technol. 2017, 227, 107-117. [CrossRef]

116. Xia, Y.C.; Li, Y.S.; Shen, X.X.; Mizu, M.; Furuta, T.; Li, C.M. Effect of dietary supplementation with sugar cane extract on meat quality and oxidative stability in finishing pigs. Anim. Nutr. 2017, 3, 295-299. [CrossRef] [PubMed]

117. El Sheikha, A.F.; Ray, R.C. Potential impacts of bioprocessing of sweet potato: Review. Crit. Rev. Food Sci. Nutr. 2017, 57, 455-471. [CrossRef] [PubMed]

118. Gonçalves Neto, Á.C.; Maluf, W.R.; Gomes, L.A.A.; Gonçalves, R.J.d.S.; Silva, V.d.F.; Lasmar, A. Aptidões de genótipos de batata-doce para consumo humano, produção de etanol e alimentação animal. Pesqui. Agropecuária Bras. 2011, 46, 1513-1520.

119. Fraser, N. Reframing justice in a globalizing world. New Left Rev. 2005, 36, 69-88.

120. Paavola, J.; Adger, W.N. Fair adaptation to climate change. Ecol. Econ. 2006, 56, 594-609. [CrossRef]

121. Cardoso, A.D.; Viana, A.E.S.; Ramos, P.A.S.; Matsumoto, S.N.; Amaral, C.L.F.; Sediyama, T.; Morais, O.M. Avaliação de clones debatata-doce em vitória da conquista. Hortic. Bras. 2005, 23, 911-914. [CrossRef]

122. Moulin, M.M.; Bento, C.S.; Júnior, A.C.S.; Rodrigues, R. Caracterização de acessos de batata-doce baseado em características morfológicas. Perspect. Online - Biológicas E Saúde 2014, 4, 23-36. [CrossRef]

123. Cruz, J.C.; Konzen, E.A.; Pereira Filho, I.A.; Marriel, I.E.; Cruz, I.; Duarte, J.D.O.; Oliveira, M.F.; Alvarenga, R.C. Importância da produção do milho orgânico para a Agricultura Familiar; Embrapa: Brasilia, Brazil, 2006.

124. Cardoso, A.D.; Viana, A.E.S.; Matsumoto, S.N.; Bomfim Neto, H.; Khouri, C.R.; Melo, T.L. Características físicas e sensoriais de clones de batata-doce. Ciência E Agrotecnologia 2007, 31, 1760-1765. [CrossRef]

125. Pipolo, V.C.; Souza, A.D.; Silva, D.A.D.; Barreto, T.P.; Garbuglio, D.D.; Ferreira, J.M. Avaliação de cultivares de milho crioulo em sistema de baixo nível tecnológico. Acta Scientiarum. Agron. 2010, 32, 229-233. [CrossRef]

126. Masiero, S.S. Microusinas de etanol de batata-doce: Viabilidade econômica e técnica; Universidade Federal do Rio Grande do Sul: Porto Alegre, Brazil, 2012.

127. Altieri, M.A.; Funes-Monzote, F.R.; Petersen, P. Agroecologically efficient agricultural systems for smallholder farmers: Contributions to food sovereignty. Agron. Sustain. Dev. 2012, 32, 1-13. [CrossRef]

128. IBGE. Censo Agropecuário 2006 Agricultura Familiar: Primeiros Resultados; Instituto Brasileiro de Geografia e Estatistica: Rio de Janeiro, Brazil, 2006.

129. Blanc, J.; Kledal, P.R. The brazilian organic food sector: Prospects and constraints of facilitating the inclusion of smallholders. J. Rural Stud. 2012, 28, 142-154. [CrossRef]

130. Fabian, S. Status quo and prospects of smallholders in the brazilian sugarcane and ethanol sector: Lessons for development and poverty reduction; Center for Development Research (ZEF), University of Bonn: Bonn, Germany, 2009.

131. Woods, M. Social movements and rural politics. J. Rural Stud. 2008, 24, 129-137. [CrossRef]

132. Lee, J.S.H.; Rist, L.; Obidzinski, K.; Ghazoul, J.; Koh, L.P. No farmer left behind in sustainable biofuel production. Biol. Conserv. 2011, 144, 2512-2516. [CrossRef]

133. Hunsberger, C.; Bolwig, S.; Corbera, E.; Creutzig, F. Livelihood impacts of biofuel crop production: Implications for governance. Geoforum 2014, 54, 248-260. [CrossRef]

134. Portaria $n^{\circ} 144$, de 22 de julho de 2019. Imprensa Nacional, 2019. Available online: http://www.in.gov.br/en/ web/dou/-/portaria-n-144-de-22-de-julho-de-2019-203419910 (accessed on 5 March 2020).

135. Abessa, D.; Famá, A.; Buruaem, L. The systematic dismantling of brazilian environmental laws risks losses on all fronts. Nat. Ecol. Evol. 2019, 3, 510-511. [CrossRef]

136. Artaxo, P. Working together for amazonia. Science 2019, 363, 323. [CrossRef]

137. Pereira, J.C.; Viola, E. Catastrophic climate risk and brazilian amazonian politics and policies: A new research agenda. Glob. Environ. Politics 2019, 19, 93-103. [CrossRef]

138. Decreto ${ }^{\circ}$ 9.759, de 11 de abril de 2019. Presidência da República, S.-G., Subchefia para Assuntos Jurídicos (Ed.) 2019. Available online: http://www.planalto.gov.br/ccivil_03/_ato2019-2022/2019/decreto/D9759.htm (accessed on 5 March 2020).

139. Projeto de lei $n^{\circ} 5695$, de 2019. Senado Federal, B., Gabinete do Senador Izalci Lucas (Ed.) 2019; Available online: https://legis.senado.leg.br/sdleggetter/documento?dm=8031546\&ts=1574183873810\&disposition= inline (accessed on 5 March 2020). 
140. Escobar, H. 'We are headed for a very dark period'. Brazil's researchers fear election of far-right presidential candidate. Available online: https://www.sciencemag.org/news/2018/10/we-are-headed-very-dark-periodbrazil-s-researchers-fear-election-far-right (accessed on 5 March 2020).

141. Scantimburgo, A. O desmonte da agenda ambiental no governo bolsonaro. Perspect.: Rev. De Ciências Sociais 2018, 52, 103-117.

142. Pettorelli, N.; Barlow, J.; Cadotte, M.W.; Lucas, K.; Newton, E.; Nuñez, M.A.; Stephens, P.A. Applied ecologists in a landscape of fear. J. Appl. Ecol. 2019, 56, 1034-1039. [CrossRef] 